\title{
THE DEVELOPMENT OF THE THYMUS.
}

BY

E. T. BELL, B. S., M. D.

Instructor in Anatomy, University of Missouri.

With 3 Plates and 5 Text Figures.

This paper is intended mainly as a contribution to our knowledge of the histogenesis of the thymus in mammals. Special attention is given to the origin and development of the corpuscles of Hassall, since their mode of formation has never been satisfactorily described in mammals and their significance in all forms is in dispute. An attempt is also made to show in detail the changes that occur during the transformation of the thymus from the epithelial to the lymphoid condition.

This work was begun at the suggestion of Dr. D. D. Lewis at the University of Chicago. The greater part of it has been done at the University of Missouri. Special acknowledgments are due Dr. C. M. Jackson for valuable criticism and suggestions. I wish also to thank Mr. Charles H. Miller of the University of Chicago for his kindness in sending me material.

\section{Material and Methods.}

As material for the greater part of my work, I have used pig embryos from $8 \mathrm{~mm}$. to full term $(26 \mathrm{~cm}$. to $30 \mathrm{~cm}$.). These are especially suitable for such work since they may be procured in abundance from the large packing houses at almost any stage of development. For special purposes I have studied a few specimens from human fotuses, and from the cat, rat, and guinea pig. The smaller pigs used $\left(8 \mathrm{~mm}\right.$. to $27 \mathrm{~mm} .{ }^{1}$ ) belong to the collection in the anatomical laboratory at the University of Missouri. These were stained in bulk with alum-cochineal and mounted in serial sections. In the later stages, which were prepared specially for this work, the ventral half of the cervical and anterior thoracic regions was usually cut out and embedded from pigs from $3 \mathrm{~cm}$. to $8 \mathrm{~cm}$. On specimens from $8 \mathrm{~cm}$. to $30 \mathrm{~cm}$., I dissected out the thymus and used such parts as were desired.

${ }^{1}$ The crown-rump measurement is used in all cases.

AMERICAN JOURNal OF ANatomy.--VOI. V. 
All pig material was fixed in Zenker's fluid, embedded in paraffin, and mounted in serial sections from $3 \mu$ to $10 \mu$ thick. Except those of the young stages $(8 \mathrm{~mm}$. to $27 \mathrm{~mm}$.) the sections were stained on the slide. Most of them were stained with hæmatoxylin or iron-hæmatoxylin and counterstained with Congo red. For special purposes many other stains were used.

To demonstrate the delicate protoplasmic threads of the syncytium during the later stages of the lymphoid transformation, I stained by the iron-hæmatoxylin method but omitted the final decolorization in ironalum. Protoplasm is stained deep black; nuclear structure is poorly shown, but the finest cytoplasmic processes may be seen.

For the demonstration of connective tissue fibrillæ in the syncytium, I found the method recommended by Jackson (13, S. 39) most satisfactory.

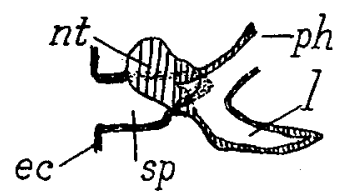

Text Fig. 1.

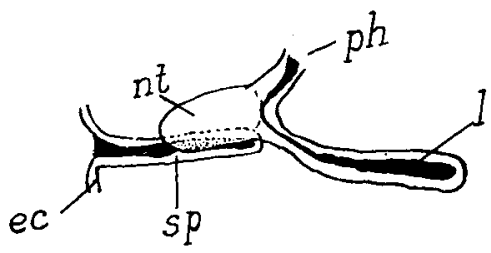

Text Frg. 2.

Text Figure 1. Cranial view of third gill pouch (thymic anlage); $\times 33$; pig embryo, $11 \mathrm{~mm}$; $e c$, ectoderm; $l$, lumen; $n t$, nodulus thymicus; $p h$, connection to pharynx; $s p$, sinus præcervicalis.

Text Figure 2. Ventral view of thymic anlage; $\times 33$; pig embryo, $15 \mathrm{~mm}$; $e c$, ectoderm; $l$, lumen; $n t$, nodulus thymicus; $p h$, connection to pharynx; $s p$, sinus præcervicalis.

To determine the relation of the blood-vessels to the corpuscles of Hassall, I put a young kitten under deep anæsthesia and injected a large quantity of a strong aqueous solution of Prussian blue into the aorta through the common carotid artery. The heart continues to beat even after an amount of fluid twice as great as the total volume of the blood has been injected. An injection made in this way is under a slightly increased blood pressure and easily reaches the finest capillaries. There is therefore a thorough injection with little danger of rupturing delicate blood-vessels.

\section{ORGANOGENESIS.}

My observations on this phase of development are not sufficiently complete to warrant a full discussion. A brief survey may however prepare the way for a better understanding of the histogenesis. The text figures show the shape in outline of the third gill pouch and thymic anlage 
from $11 \mathrm{~mm}$. to $27 \mathrm{~mm}$. They are graphic reconstructions. Since this pouch is nearly all converted into thymus it may be regarded as the thymic anlage from a very early stage.

At $11 \mathrm{~mm}$. (Text Figure 1), the pouch is a hollow epithelial tube directed from without ventrally and mesially. The lumen $(l)$ is large and communicates freely with the pharynx. On the dorso-lateral aspect of the pouch is a solid epithelial mass $(n t)$ distinctly different in structure from the rest of the pouch. This is the nodulus thymicus (Kastschenko, 14) and will be referred to by that term. This structure has been described by Stieda (26), Prenant ${ }^{2}$ (22), and others as the anlage of the carotid gland.

It was evidently mistaken by Minot $^{3}$ in a $12-\mathrm{mm}$. pig for the anlage of the entire thymus. It may be seen as early as the $8 \mathrm{~mm}$. stage budding off from the cranio-lateral aspect of the pouch. Immediately behind the nodulus thymicus, but not connected to it at this stage is the inner blind extremity of the sinus præcervicalis $(s p)$. These become fused at $12 \mathrm{~mm}$. or $13 \mathrm{~mm}$.

At $15 \mathrm{~mm}$. (Text Figure 2) the thymic anlage is more elongated. It now projects ventrally and medianwards, its free end lying immediately caudad to the median thyroid anlage and just craniad to the pericardium. Its lumen $(l)$ is still in communication with the pharynx. The sinus præcervicalis $(s p)$ is drawn out, its lumen being smaller and longer. It is now fused to the outer two-thirds of the posterior aspect of the nodulus thymicus $(n t)$.

At $18 \mathrm{~mm}$. (Text Figure 3) the anlage is growing rapidly in a caudal direction and just entering the thoracic cavity. It is connected to the pharynx by a delicate epithelial cord. There is still a lumen in its caudal part. The sinus præcervicalis has lost its connection to the nodulus thymicus." The outer part of its lumen has disappeared and it seems about to lose its connection with the ectoderm.

At $20 \mathrm{~mm}$. (Text Figure 4) the thymus extends well into the thoracic cavity. Its thoracic segment $(t h)$ has increased considerably in size and is united to the gland of the opposite side.

The nodulus thymicus still forms the greater part of the head. The anlage has no connection with the pharynx or the epidermis. There is

2Prenant is said to have since abandoned this idea and accepted Kastschenko's view. (v. Ebner in Kölliker's Gewebelehre des Menschen. Aufl. 6, Bd. 3, 1, S. 340.)

${ }^{3}$ Laboratory Text of Embryology, p. 191; also p. 209 and Fig. 124.

- On the opposite side in this specimen, these structures were fused over a very small area. 
now an elongated mass of thymic tissue extending upwards behind the nodulus thymicus, and fused with it. Its upper pointed extremity curves outwards around the hypoglossal nerve. This is the "thymus superficialis" ( $t s)$ of Kastschenko and is regarded by him as being formed from the sinus præcervicalis. Kastschenko describes this elongated portion as being always separate from the rest of the head, being connected only by connective tissue. In my preparations it is clearly continuous with the rest of the anlage, and seems to have formed by growing out from it. The presence of a lumen in its lower end favors Kast-

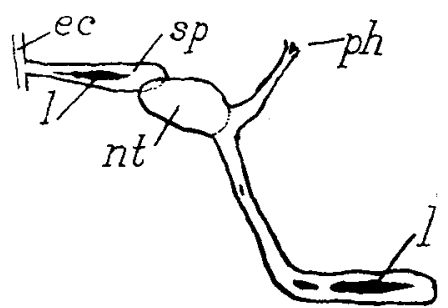

TEXT FIG. 3.

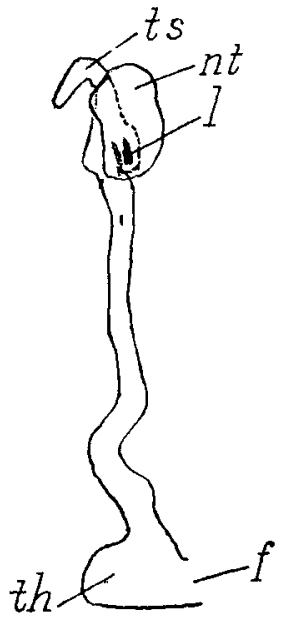

Text Fig. 4.

Text Figure 3. Ventral view of thymic anlage; $\times 33 ;$ pig embryo, $18 \mathrm{~mm}$.; $e c$, ectoderm; $l$, lumen; $n t$, nodulus thymicus; $p h$, connection to pharynx; $s p$, sinus præcervicalis.

Text Figure 4. Ventral view of thymic anlage; $\times 33 ;$ pig embryo, $20 \mathrm{~mm}$.; $f$, area fused with gland of opposite side; $l$, lumen; $n t$, nodulus thymicus; $t h$, thoracic segment; $t s$, thymus superficialis.

schenko's view, for there is no lumen in the head at $18 \mathrm{~mm}$. in my preparations. On the other hand the separation from the head at the $18 \mathrm{~mm}$. stage favors the idea that the sinus præcervicalis degenerates. I have not studied a sufficient number of specimens at this transition stage to enable me to decide this point, though I believe the ectoderm takes no part in the formation of the thymic anlage. Kastschenko's results are opposed by nearly all other students of this problem, but his work should not be discarded before the development of the thymus superficialis in the pig has been accurately determined.

At $27 \mathrm{~mm}$. (Text Figure 5) the thymus is much longer and extends 
well down into the thoracic cavity in relation to the base of the heart where it has fused with the gland of the opposite side. Buds are now beginning to form through the greater part of its extent. 'Traces of the original lumen $(l)$ may still be seen in several places. The "thymus superficialis" is bent around the twelfth nerve. A delicate cord of thymic

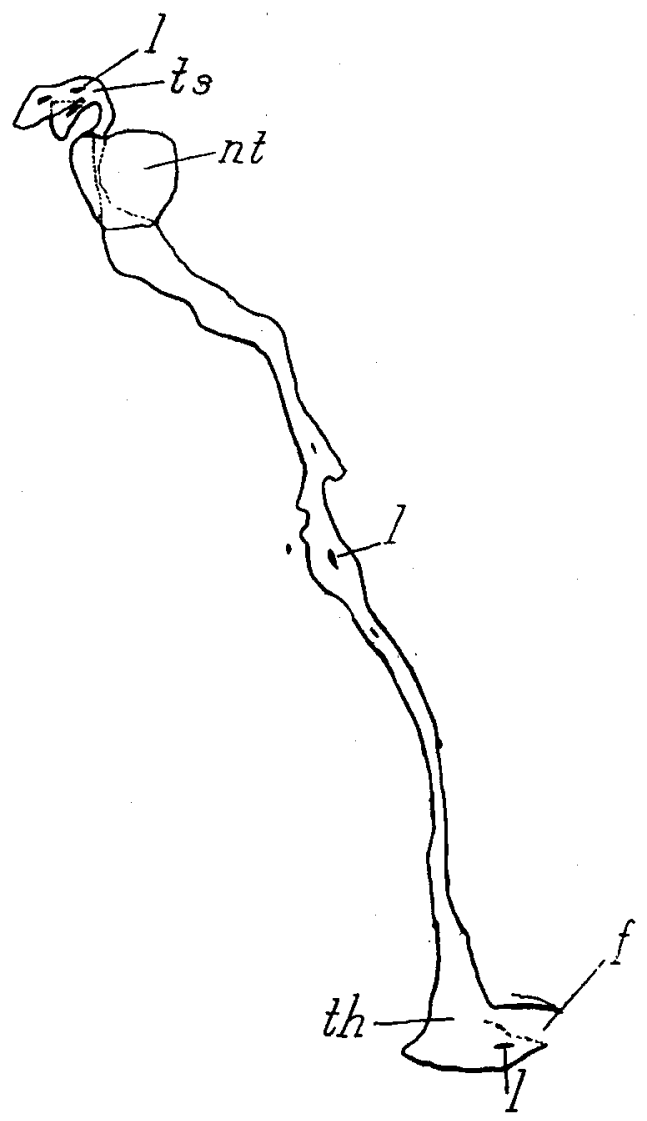

Text FIg. 5 .

Texr Figure 5. Ventral view of thymic anlage; $\times 33$; pig embryo, $27 \mathrm{~mm}$; $f$, area fused with gland of opposite side; $l$, lumen; $n t$, nodulus thymicus; $t h$, thoracic segment; $t s$, thymus superficialis.

tissue fused with the back of the nodulus thymicus connects the thymus superficialis to the rest of the head.

From about $3 \mathrm{~cm}$. until toward the end of fœetal life the thymus shows the two constrictions, described by Prenant (22) (for the sheep) as the intermediary and the cervico-thoracic cords. These cords connect three 
enlargements which we may call the head, the mid-cervical segment, and the thoracic segment. I will consider each part separately. The thoracic segment develops rapidly, spreading out above and in front of the heart. The glands of the two sides fuse completely in this region. The lymphoid transformation is noticeable at $3.5 \mathrm{~cm}$. and well advanced at $4.5 \mathrm{~cm}$. The medulla begins to form at $8 \mathrm{~cm}$. The cervico-thoracic cord is at first very narrow but soon thickens and joins the cord of the opposite side. At full term they form a sharp constriction, $3 \mathrm{~mm}$. to $4 \mathrm{~mm}$. wide and $5 \mathrm{~mm}$. to $6 \mathrm{~mm}$. long, situated at the superior aperture of the thorax, and connecting the mid-cervical and thoracic segments. The histological changes take place here later than in the enlargements.

The mid-cervical segment develops like the thoracic segment but somewhat more slowly. Budding, lymphoid transformation, and formation of the medulla all begin here a little later than in the head and thoracic segment. Its caudal end is slightly in advance of its cranial end. The intermediary cord is well marked at $4 \mathrm{~cm}$. It soon becomes very attenuated, having at $6 \mathrm{~cm}$. in many places a diameter of only $15 \mu$. Prenant suggests that this drawing out of the gland is caused by the rapid growth of the neck. Later it increases in size and at full term is noticeable only as a very slight constriction between the head and the mid-cervical segment. The histological changes are much later here than in other parts of the gland.

The greater part of the head in the early stages is formed by the nodulus thymicus. This body grows slowly, attaining a diameter in crosssection of $.5 \mathrm{~mm}$. at $8 \mathrm{~cm}$. Its cross-sectional area at $8 \mathrm{~cm}$. is about onethird that of the rest of the head of the thymus. At this stage the nodulus thymicus is a rounded body lying on the inner aspect of the head in relation to the carotid artery. A small area of its outer surface is fused with the lymphoid tissue of the thymus. Its histological strueture has been fully described by Prenant (22). From the earliest stages, it consists of cords of epithelial cells separated by blood capillaries. At $8 \mathrm{~cm}$. the thymus superficialis (Kastschenko) is a large body lying craniad and dorsal to the rest of the head but connected to it at its caudal extremity.

I have no observations on the head of the thymus between $8 \mathrm{~cm}$. and full term, having overlooked it in collecting my material. In a full term pig $(30 \mathrm{~cm}$.$) , the cervical part of the thymus is in two distinct parts.$ The postero-ventral part, representing part of the head, the intermediary cord, and the mid-cervical segment, is about $3 \mathrm{~cm}$. long and $1 \mathrm{~cm}$. wide. It extends from the upper border of the thyroid cartilage to the thorax, and with the corresponding part of the opposite gland encloses the 
trachea, thyroid, and lower part of the larynx. A slight narrowing at the junction of the upper and middle thirds indicates the position of the intermediary cord. The antero-dorsal part, the thymus superficialis, is rounded in cross-section, tapering to a point behind. Its anterior end is about $7 \mathrm{~mm}$. in diameter and loops around the twelfth nerve as in the earliest stages. A lobule hangs over ventral to the nerve, a thin cord being dorsal to it. The posterior end of the thymus superficialis extends to the cricoid cartilage dorsal to the postero-ventral part of the gland. It is united to this part of the gland by a very delicate band of thymic tissue. I did not find the nodulus thymicus at full term. It has either moved away from the head or degenerated.

The duct of the thymus is the lumen of the third gill pouch. A glance at the Text Figures will show its development. It is broken up into segments and finally obliterated. I could find no traces of it at $3.7 \mathrm{~cm}$. or later. On the theory of the exclusively endodermal origin of the thymus, I cannot explain the absence of a lumen in the head at $18 \mathrm{~mm}$. and its presence at $20 \mathrm{~mm}$. and $27 \mathrm{~mm}$. unless it be due to individual variation in different specimens.

It appears from the foregoing that in the pig the exclusively endodermal origin of the thymus from the third gill pouch is probable, but a slight participation by the ectoderm has not been satisfactorily excluded. Kastschenko's conclusions, however, as to the ectodermal origin of the thymus are unwarranted by his recorded observations. Prenant, after his careful work (on the sheep), was not sure that a small mass of ectoderm did not enter into the formation of the head. Practically all other investigators of this problem maintain that the ectoderm takes no part in the formation of the thymus. The epithelial body (nodulus thymicus) developing in connection with the head of the thymus from the third gill pouch does not form the carotid gland. Kastschenko's description of the origin of the carotid gland in mammals from the adventitia of the internal carotid is now accepted by the majority of anatomists, and it therefore has nothing to do with the thymus in origin.

\section{The Histology of the Fully-Formed Thymus.}

Before taking up the histogenesis, I shall briefly consider the histology of the gland as shown in a $24-\mathrm{cm}$. embryo. At this stage the gland may be regarded as fully formed. As is well known, the thymic lobule consists of a cortical and a medullary portion,- - the medulla of all the lobules being united by the medullary cord. The cortex consists of a delicate reticulum with its spaces well filled by cells, usually lymphocytes. The reticulum may be regarded as composed of small branched anastom- 
osing cells, though of course no cell boundaries are distinguishable. The nuclei are poor in chromatin, rounded, and usually $4.5 \mu$ to $5.5 \mu$ in diameter. The amount of cytoplasm around the nuclei and connecting them is usually very small. At some nodes there is a greater amount of cytoplasm giving the appearance of a large reticulum cell. In connection with the blood-vessels, which are numerous in the cortex, are often found branched cells with pale nuclei and cytoplasm that stains more intensely than that of the rest of the reticulum. By a modification of Mallory's method used by Jackson (13, S. 39), I have been able to demonstrate numerous fibrillæ in the reticulum. In some cortical areas at this stage there are a great many erythroblasts. Masses of free erythrocytes are often found, usually near a comparatively large vessel, but such cells occur singly anywhere in the cortex.

In the medulla, the syncytial character of the stroma is much more pronounced. The cytoplasm is much more abundant than in the cortex, and the spaces are smaller and not so numerous. There is not so much room for lymphocytes as in the cortex, hence the lighter color of the medulla in stained preparations. The nuclei of the syncytium are either pale or dark, both types showing wide variations in size. By Jackson's method (13, S. 39), fibrillæ may be readily demonstrated in the syncytium. In Plate I, Fig. 6, is shown the arrangement of these fibrillæ $(s f)$ in the medulla at $24 \mathrm{~cm}$. They often may be traced into the areas which are forming the concentric corpuscles. In some parts of the medulla the fibrillæ are very numerous; in a few places, entirely absent. In both cortex and medulla eosinophile cells are often found. These occur in groups in the interlobular tissue around the blood-vessels, around some of the corpuscles of Hassall, and singly in the reticulum. These have been described by Schaffer (24). Free erythrocytes are rarely found in the medulla. In the medulla are also found the corpuscles of Hassall. Since the structure of these bodies depends largely upon their age, it may be better understood from the consideration of their development.

\section{The Lymphoid Transformation."}

Kölliker, in 79, first advanced the idea that the leucocytes are formed directly from the epithelial cells of the thymic anlage. According to Minot (in human embryology, p. 878), "he records for the rabbit that between the twentieth and twenty-third days the cells of the thymus become smaller and their outlines disappear, so that the organ appears to

$\checkmark$ This term will be used to include those changes that occur in the thymus during its passage from an epithelial to a characteristic lymphoid structure. 
be an accumulation of small round nuclei. At about the same period blood-vessels and connective tissue grow into the epithelial anlage."

His (12 b), 80, and Stieda (26), 81, claimed that the corpuscles of Hassall are the only remnants of the epithelial anlage, that the lymphocytes, reticulum, etc., are of mesenchymal origin.

Maurer (17 a), 86, described the leucocytes as arising directly from the cells of the epithelial anlage in the thymus of teleosts. In the amphibian thymus $(17 \mathrm{~b}), \mathbf{8 8}$, he thinks that the leucocytes are probably of mesenchymal origin. He was unwilling to conclude that they arose from the epithelium because he could not find transition forms. In lizards $(1 \% \mathrm{c})$, 99, he records that even before the separation of the epithelial anlage of the thymus from the pharynx, changes begin. The peripheral cells are closely crowded together and show many mitoses. There arises between the central cells, or is formed in vacuoles in their protoplasm, a fluid which accumulates until the nuclei surrounded by a thin zone of protoplasm are connected only by protoplasmic threads. A loose medulla is thus formed which looks like a cellular reticulum. The cortex is still solid. The lymphocytes are formed from the epithelial cells; none come from without. Later, blood-vessels and connective tissue grow in. He believes that the reticulum is of mesenchymal origin in all forms. Maurer $(17 \mathrm{~d})$, 02, still holds that in amphibians the lymphocytes are probably of mesenchymal origin.

Hermann et Tourneux (11), 87, find that in man and other mammals the epithelial anlage of the thymus is gradually converted into leucocytes and reticulum cells. Vacuoles appear during the transformation which seem to be formed by the absorption of large cells. In a sheep embryo of $130 \mathrm{~mm}$., the clear epithelial cells have all disappeared, giving rise to small round cells and reticulum cells. Prolongations of connective tissue, each containing a blood-vessel, grow into the anlage during the transformation. They are not sure that all the thymic elements are epithelial in origin, being especially in doubt about the origin of some of the reticulum cells.

Gulland (8), 9r, describes the development of the tonsil in the rabbit. Leucocytes first appear in the connective tissue around the thymus. Later they appear in the connective tissue around the tonsil. They infiltrate the tonsillar epithelium. No leucocytes are of epithelial origin. After studying the tonsil he examined the thymus in a few specimens and concluded that the same process of leucocyte infiltration occurred there. He does not give the details of their infiltration, and did not see any of the transition forms of nuclei in the chymus at that period.

Prenant (22), 94, made a careful study of the development of the 
thymus in sheep embryos. His results are as follows. At $25 \mathrm{~mm}$. the gland is composed of distinct polyhedral cells with nuclei of only one kind. A few mitoses and an occasional direct division are to be seen. At $26 \mathrm{~mm}$. mitoses are numerous (one nucleus in fifty). Nuclei are regularly rounded or elliptical and some small nuclei occur juxtaposed to large nuclei. At $28 \mathrm{~mm}$. many mitoses are present and irregular spaces have appeared. These spaces are not blood-vessels nor parts of the thymic duct but vacuoles. Some nuclei, noticeably small and dark]y colored, lie close to the large, clear nuclei and seem to be budded off from them. Some nuclei (rare) are broken into three or four chromatic bodies. Fmbryos of $40 \mathrm{~mm}$. have undergone in great part the lymphoid transformation. All transitions are found between the large, pale elliptical nuclei of clear reticular structure and the small, deeply colored rounded nuclei whose sap is strongly stained. These last are certainly lymphocytes and constitute an immense majority of the cellular elements. Large, clear nuclei are found joined to small dark ones-nuclear couples.

At $85 \mathrm{~mm}$. the medulla appears; the cortex corresponds to the entire thymic mass of preceding stages. The cortex contains a great many lymphocytes separated by islands and rows of pale nuclei. There are about thirty lymphocytes to one pale nucleus. Mitoses are numerous in the cortex. In the medulla at this stage, the large clear, and small dark, nuclei are about equal in number, and mitoses are rarer than in the cortex. In later embryonic stages a clear peripheral zone is present where cell proliferation takes place. Mitoses are now more numerous in the medulla than in the cortex. It is probable that a certain number of the epithelial cells persist as reticulum cells in the fully-formed organ.

J. Beard (3 a), 94, (3 b), 99, thinks that the function of the thymus is to form the first leucocytes. He finds that in the skate the epithelial cells are converted early into lymphocytes which emigrate into the blood. There are many breaks in the gland where the lymphocytes escape in masses. The thymus is the only source of leucocytes until the other lymphoid organs are formed.

Ver Eecke (28), 99, finds that in the frog the epithelial thymus is invaded by lymphocytes and connective tissue. The epithelial cells are not destroyed but merely dispersed by the mesenchymal elements. $\mathrm{He}$ calls the resulting tissue lympho-epithelial. This idea of the commingling of the two tissues had already been advanced by Retterer.

Nusbaum and Prymak (20), or, on teleosts, agree with Maurer that the lymphocytes are of epithelial origin but disagree on the details of their formation. They find that the epithelial anlage is at first composed of cells with distinct boundaries. It is not different from the epithelium 
of the pharynx. Before any blood-vessels or connective tissue have invaded the organ, changes begin in the central part. These changes consist in the breaking up of the cytoplasm so that the cells become branched and connected by delicate processes. These processes finally break apart leaving a nucleus surrounded by a thin layer of protoplasma lymphocyte. The peripheral epithelial layer multiplies rapidly, forming nuclei somewhat smaller and darker than their own. These nuclei become gradually changed into the nuclei of lymphocytes and break away from the other cells. All transitions are present between the large, clear epithelial nuclei and the lymphocytes. Blood-vessels and connective tissue grow in from the outside.

It appears from a survey of the literature that, of those who have studied the origin of lymphocytes in the mamalian thymus, His, Stieda, and Gulland have advocated the idea that they invade the gland from without, and that the original epithelial anlage persists only as remnants, the corpuscles of Hassall. They also consider the stroma of mesenchymal origin. On the other hand, Kölliker, Hermann and Tourneux, and Prenant, have described the lymphocytes as derived directly from the epithelial cells of the anlage. Hermann and Tourneux and Prenant ascribed a similar origin to part of the reticulum.

Neither His, Stieda, nor Gulland made a detailed histological study of the changes that take place in the thymus during the transformation. They did not see the vacuolization of the cytoplasm, the changes in the epithelial nuclei, etc.-processes which undoubtedly occur. Gulland made nearly all his observations on the tonsil and then from a superficial examination of the thymus concluded that the process is the same there. The conclusions of these men are therefore not to be compared on this point with those obtained by the thorough and careful work of Prenant.

On amphibians, Maurer hesitatingly agrees with His, and Ver Eecke accepts the mesenchymal origin of the leucocytes; while on fishes Maurer, Beard, and Nusbaum and Prymak believe in the epithelial origin of lymphocytes. Maurer's work on reptiles is in agreement with his work on teleosts.

As to the origin of leucocytes in the lymphoid organs of the alimentary canal, opinion is divided. Retterer, v. Davidoff, Rudinger, Klaatsch, and others have described the leucocytes as arising from epithelium and being invaded by mesenchymal elements forming adenoid tissue. Stöhr, Gulland, Tomarkin, and others describe them as penetrating the epithelium from without.

I shall now discuss my own observations on the lymphoid transformation in the thymus of the pig. From a very early stage $(11 \mathrm{~mm}$.), the 
epithelium of the third gill pouch is a syncytium. No cell boundaries exist. The nuclei, large and irregular in shape, are embedded in a common mass of cytoplasm. In the thymus at $20 \mathrm{~mm}$. I find a syncytium of dense cytoplasm embedded in which are large nuclei of irregular shape and size. No distinct types of nuclei are present yet; all stain with medium intensity. A few mitoses are to be seen.

In a section of the mid-cervical segment at $3.7 \mathrm{~cm}$. (Plate I, Fig. 1), I find evidence that the lymphoid transformation has begun. The syncytium is composed of coarsely reticulated cytoplasm much looser in texture than that of the preceding stage. It contains a few irregular spaces $(s s)$ which are evidently of the nature of vacuoles. These may be formed, as Maurer suggests, by liquefaction of the cytoplasm. There is no reason to suppose that cells degenerate and form them as Hermann and Tourneux believed. Three types of nuclei may be distinguished; large pale nuclei $(l p n)$ large dark nuclei $(l d n)$, and small dark nuclei (lymphoblasts) ( $l b)$. Transition forms oceur between these types. The large dark nuclei are intermediate forms between the pale nuclei and the lymphoblasts. A few mitoses $(m)$ occur. No blood-vessels are present inside the anlage but they may be seen between the buds just outside. At this stage, the head and the thoracic segment have areas that are somewhat farther advanced than this. The intermediary and cervico-thoracic cords show no changes.

At a later stage than the above (Plate I, Fig. 2), in the thoracic segment of a $4.5-\mathrm{cm}$. pig, the spaces of the syncytium $(s s)$ have increased greatly in number and size. The anlage is now a cellular reticulum. The large pale nuclei are somewhat less numerous than the dark nuclei and many have become angular, adapting themselves to the nodes of the syncytium. They contain less chromatin than in the preceding stage. Large dark nuclei and lymphoblasts are present; the lymphoblasts are much more numerous than in the preceding stage. A very few small dark nuclei are completely separated from the syncytium. These are lymphocytes. There are no lymphocytes in the connective tissue around the thymus or in the blood at this stage. I did not examine the tonsil or spleen at any stage. A few small blood-vessels are to be seen; their walls consist of endothelium only. There are more mitoses than at the preceding stage, but none happened to be present in the area shown in the figure. During mitosis, at all stages of development, except the early epithelial condition, the chromosomes are so closely packed that it is very difficult to distinguish them individually.

In a section through the mid-cervical segment of a $7-\mathrm{cm}$. pig (Plate I, Fig. 5), we see a stage somewhat later than the one shown in 
Fig. 2. In various parts of the section lymphocytes ( $l$ ) are completely formed. The great majority of the small round nuclei are in the lymphoblast $(l b)$ condition, i. e., they are not yet completely separated from the syncytium. There are a few lymphocytes outside the thymus in the interlobular tissue in this region; around the head and the thoracic segment at $7 \mathrm{~cm}$. they are numerous, these parts being in a later stage of transformation. I have never seen lymphocytes outside the thymus, where there were none inside it; but they appear outside shortly after they are formed here. Those formed next the interlobular septa seem to pass out very early. Of course the lymphoblasts, which are distinguishable from the lymphocytes only by being imbedded in the syncytium, are to be seen in the thymus long before any appear outside.

At the stage shown in Fig. 5, a great many nuclei are in mitosis. I have not seen at any stage, the amitoses and nuclear couples described by Prenant for the sheep. In some parts of the section comparatively large solid epithelial areas occur. These are found as often in the central as in the peripheral part. Many of the pale nuclei are smaller than those shown in Fig. 2. The blood-vessels are somewhat larger and more numerous than those at $4.5 \mathrm{~cm}$.

It is to be noted that the epithelial anlage does not at any stage become converted entirely into small round cells as many observers have stated. Distinctly pale angular reticular nuclei can always be seen.

In the mid-cervical segment at $8.5 \mathrm{~cm}$. (Plate I, Fig. 4), a great nany lymphocytes $(l)$ are formed. These lie between the persisting epithelial cells which are now arranged in irregular cords and islands. In these epithelial masses, lymphoblasts may still be seen indicating that the formation of lymphocytes is still in progress. Many of the pale nuclei are now small. The heavy hæmatoxylin stain in this case makes the nuclei darker than they would appear with an ordinary stain. A few nuclei are in mitosis.

This figure shows also the first appearance of the medulla $(m d)$. The medulla is formed directly, as shown in the figure, from persisting parts of the epithelial syncytium. Certain centrally situated masses of this syncytium undergo changes of such a nature that they stain readily with cytoplasmic stains such as Congo red. In sections stained with hæmatoxylin and Congo red, the medulla is first recognized as a brightly colored area situated usually about the center of the lobule. These epithelial masses that give rise to the medulla seem to increase in size about the time of the change in staining capacity. The first differentiation of the medulla is chemical rather than morphological, for there'are other persisting epithelial masses even larger than it in the same section 
that do not react in the same way with the cytoplasmic stains. The medulla appears in the head and the thoracic segment at $7.5 \mathrm{~cm}$. to $8 \mathrm{~cm}$. All the gland except this small central area forms the cortex. Bloodvessels now reach all parts of the gland, but are still few in number. I cannot distinguish any wall except the endothelium on those actually inside the gland.

In a 9.5-cm. pig, the medulla is larger. It contains pale nuclei of various sizes, large dark nuclei, and lymphoblasts. Its spaces are smaller than those of the cortex. The early stages in the formation of the corpuscles of Hassall appear as soon as the medulla begins to form. The epithelial cords in the cortex have become less conspicuous, but are still forming lymphocytes. A few nuclei are in mitosis. Many blood capillaries may now be seen penetrating the gland from the periphery. These vessels run in the epithelial masses and have a wall of large endothelial cells which gives them the appearance of radiating cords. When these vessels first appear, as at this stage, they have only an endothelial wall. The blood-vessels grow in as small capillaries which, after their entrance, increase in size and branch; they do not break in as large vessels surrounded by mesenchymal tissue. I am fairly sure that aside from the endothelial cells few or no mesenchymal cells come into the thymus. Around the greater part of the periphery of the gland is a solid zone of syncytium two or three nuclei deep which is in transformation like the epithelial cords inside. This zone, described by Prenant as a zone of proliferation, grows rapidly, as the frequent mitoses indicate. Its inner boundary is forming lymphocytes and reticulum cells.

In a 14-cm. pig, the lymphoid transformation is practically at an end except in the medulla. The peripheral zone of proliferation has disappeared. The cortex has about the same structure as at $24 \mathrm{~cm}$., as previously described. In the medulla, lymphoblasts, large pale nuclei, and the large dark intermediate types are still present. There are a few mitoses here. It is very probable therefore that the formation of lymphocytes is still in progress in the medulla. The medulla at $24 \mathrm{~cm}$. shows a similar structure except that there are fewer lymphoblasts. These facts persuade me to regard the medulla as a center for lymphocyte formation at least as late as birth. Connective tissue fibrillæ begin to appear in the gland along the large blood-vessels and the interlobular septa as early as $10.5 \mathrm{~cm}$. They are only a little farther in at $16 \mathrm{~cm}$.; but near full term they are present in nearly all parts of the stroma. (See Plate I, Fig. 6.)

The above account may be summarized as follows: In the pig the epithelial syncytium of the thymic anlage becomes loosened up by the 
formation of vacuoles in it. These vacuoles increase in number and size, converting the anlage into a cellular reticulum. While this vacuolization is in progress, the nuclei, which at first are of one kind with a medium amount of chromatin, differentiate into large clear, large dark, and small dark (lymphoblast) forms. The large dark nuclei probably divide by mitosis and form the lymphoblasts. The lymphoblasts gradually break loose from the syncytium, passing into its spaces and becoming lymphocytes. Shortly after lymphocytes begin to be formed, some of them pass out of the gland into the surrounding connective tissue. The lymphoid transformation begins in embryos of $2.5 \mathrm{~cm}$. to $3 \mathrm{cin}$. and continues in the cortex until $12 \mathrm{~cm}$. or $13 \mathrm{~cm}$. In the medulla it is not complete at birth. Since the thymus increases greatly in size during this period the epithelial syncytium must grow rapidly. Lymphocytes are constantly being formed at the expense of the growing syncytium. A peripheral zone of proliferation is present from about $8 \mathrm{~cm}$. to $12 \mathrm{~cm}$. The medulla is formed as a chemical differentiation of certain centrally situated areas of the epithelial syncytium. The histological changes occur earlier in the head and thoracic segment than in the mid-cervical segment and very much earlier than in the cords. The reticulum of both cortex and medulla is practically all of epithelial origin. Some branched cells around the blood-vessels in the cortex may be of mesenchymal origin.

My reasons for regarding the lymphocytes as of epithelial origin are as follows:

A. 'The lymphoblasts are true epithelial nuclei, because (1) there are numerous transition forms between them and the large dark nuclei which later cannot be regarded as invading lymphocytes; (2) they are closely embedded in the syncytium and show no evidence of having eaten their way through the protoplasm; (3) they are present from a very early stage and increase in number as development proceeds; (4) they are present before blood-vessels invade the gland and have no constant relation to blood-vessels or to the surface of the gland that indicates an invasion from either of these directions; (5) they are present before lymphocytes appear in the connective-tissue around the thymus.

$B$. Some observers admit that the small dark nuclei (lymphoblasts) are of epithelial origin but do not admit that they form lymphocytes. The considerations that lead me to believe that the lymphoblasts do form the lymphocytes are: (1) the small dark nuclei (lymphoblasts) show every possible relation to the syncytium from being completely embedded in it to lying free in the syncytial spaces. A comparison with later stages shows that this appearance is not tue to poor fixation or to the 
adherence of the nuclei to the reticulum; (2) the first free nuclei often appear in the center of the gland when there are no other free nuclei in the periphery at that level; (3) there is good evidence that lymphocytes emigrate from the thymus in large numbers. If we examine the thymus of a $\%-\mathrm{cm}$. pig in serial sections we find that the lymphoid transformation is less advanced in the mid-cervical segment than in the head. In the mid-cervical segment there are a few lymphocytes in the interlobular tissue. In the lower end of the head where there are more lymphocytes inside the gland, lymphocytes pack the interlobular tissue and form a thin zone around the periphery of the gland. In the middle of the head where the transformation is far advanced, lymphocytes pack the interlobular tissue and form a thick zone around the entire gland. Indeed, in some sections, there are more lymphocytes in the zone outside than are present inside the gland. If this zone of lymphocytes be passing into the gland, it is not easy to understand why it is formed from within outwards, and why it is thickest where the greatest number of lymphocytes are already present inside. No satisfactory suggestion has yet been made as to why lymphocytes should thus suddenly pour into the thymus at a time when if present at all elsewhere they are rare. They do not come to break up the thymic epithelium, for that is already a reticulum before free cells are present (Fig. 2, Plate I). Where lymphocytes invade intestinal epithelium as in the tonsil they eat paths through it leaving spaces. The epithelial reticulum of the thymus is not formed in that way. On the other hand it is not difficult to believe that this zone of lymphocytes is formed by cells passing out the periphery of the thymus and that the gland thus contributes a great number of lymphocytes to the organism; (4) I have not been able to find lymphocytes in the connectivetissue around the thymus before they are present inside. An invasion by way of the blood-vessels may be excluded, since the thick zone of lymphocytes formed around the gland shows that these cells either enter or leave it through the preiphery.

\section{The Corpuscles of Hassalu.}

These bodies were first mentioned by Hassall (10) in 46 . He speaks of them as being composed of mother cells which enclose the newlyformed daughter cells and nuclei. He thought the central mass was formed by the outer enclosing layers. He found bodies which he regarded of the same nature in fibrous coagulations in the heart.

Virchow (29), 5I, in a discussion of endogenous cell formation, compares Hassall's corpuscles to carcinoma pearls. He had about the same 
conception of the nature of the corpuscles as Hassall. This oft-quoted comparison was therefore not based upon a deep insight into their nature.

Günzburg (9), 57, did not advance beyond Hassall's conception that the central mass is formed by the peripheral layers.

Paulitzky (21), 63, described the center of the corpuscles as homogeneous or granular. They sometimes contain an elliptical nucleus, sometimes fat droplets. The larger ones have in the center several nuclei or cell-like forms. The central part is formed from masses of epithelial cells. Connective tissue cells grow around them and are transformed into epithelial cells forming the peripheral part of the corpuscle.

The term "concentric corpuscles" was introduced by Ecker (6), who described them as arising directly from gland cells by fatty metamorphosis. He distinguished (1) simple corpuscles, round vesicles with thick concentric hulls, containing inside a fatty opalescent mass, and (2) compound corpuscles, which consist of several vesicles with a common hull. The peripheral layers of a corpuscle consist of flattened cells.

His (12 a, $12 \mathrm{~b}), 60,80$, described the corpuscles as consisting of an outer striated shell, probably composed of nucleated cells, and containing lymphocyte-like cells inside. He supposed them to be the original cells of the epithelial anlage which become entangled in the reticulum in some way. Their rapid growth in their narrow confines causes the concentric form.

Cornil et Ranvier (5), 69, considered the corpuscles as arising from the endothelium of blood-vessels and compared them to the spheres of their "Sarcôme angiolithique."

This suggestion of a vascular origin, made by Cornil et Ranvier, was elaborated by Afanassiew (1a), 77 .

Afanassiew held that the corpuscles of Hassall arise from the endothelium of the smaller veins and capillaries. The endothelial cells increase in size, become cubical, and later fill the lumen of the vessel. During the proliferation of the endothelium, the blood-vessels break up into segments which are now nearly solid cords. These cords are at first connected to each other and to blood-ressels, but they soon break apart. The surest proof that the corpuscles are of vascular origin is that erythrocytes may be found inside them. Vascular injections, however, do not go into a corpuscle except in a very early stage, since the lumen is soon obliterated by the endothelial plugs. The corpuscles are formed entirely by the endothelial cells. Afanassiew worked on embryos of man, the rabbit, and the calf.

Stieda (26), 8I, in sheep embryos, describes the epithelia] mass of the 
thymic anlage as being broken up by ingrowing adenoid tissue. From $50 \mathrm{~mm}$. to $60 \mathrm{~mm}$., there are no large epithelial cells; but later at $100 \mathrm{~mm}$. he finds in the adenoid tissue large cells $9 \mu$ to $15 \mu$ in diameter, isolated or united in groups, whose protoplasm colors light-red with carmine. These large cells have a concentric structure. Some of them are enclosed by large cells whose cytoplasm does not color with carmine, giving rise to a yellowish mass of irregular form and stratified appearance. In older embryos (250 mm.), the cellular masses are numerous but the large colored cells are rare. The yellowish masses are groups of the large cells which have undergone a transformation like that of the stratum corneum of the epidermis. Stieda considers the large colored cells which form the corpuscles as remnants of the epithelial anlage, although he admits that for a long period during development he found no trace of them. $\mathrm{He}$ explains the formation of the corpuscles in accordance with Cohnheim's hypothesis that most tumors' arise from unused tissue remnants.

Ammann (2) 82, made most of his observations on human fotuses. He describes the corpuscles as arising from connective tissue. The corpuscles are cellular in structure and are formed of one, two, or three central cells around which a variable number of cells, increasing with age, are arranged like the coats of an onion. The corpuscles are formed from reticulum cells and leucocytes. Growth consists in the apposition of cells from without. The life of a corpuscle consists usually of four stages: (1) Stadium der Transparenz; (2) Stadium der colloiden Entartung; (3) Stadium der Verkalkung; (4) Stadium des Zerfalls. The nucleus of a reticulum cell or leucocyte increases in size at the expense of the cell body. Its increase in size establishes the concentric form. The corpuscle undergoes colloid and usually calcareous degeneration. Fat droplets, cholesterin crystals, and colloid granules are found together in the degenerating corpuseles. Breaking up in this way makes absorption possible. No epithelial remnants are to be observed. No erythrocytes are found in the corpuscles.

In four cases of atrophic thymus gland which yet contained lymphoid tissue Ammann found corpuscles in all stages of development. He also found that the corpuscles are formed most rapidly when the thymus is at the height of its development. From these facts he concluded that they are not connected with the involution of the thymus as Afanassiew thought. He thought that their formation is due to a physiological decrease in the intensity of growth of the medulla, due to the rapid growth of the cortex.

Watney (31), 83, agreed with Ammann that the corpuscles arise from connective tissue cells. 
Monguidi (18), 85, distinguished true and false concentric corpuscles- the latter being only sections of blood-vessels.

Hermann et Tourneux (11), 87, gave a description of the structure and formation of the concentric corpuscles about like that given by Ammann except that they regard the reticulum cells from which the corpuscles develop as of epithelial origin.

Gulland (8), 9I, regarded the corpuscles as epithelial remnants and compared them to the epithelial pearls of the tonsil.

Maurer $(17 \mathrm{c})$, 99, described the corpuseles as epithelial in origin. His description of their formation is however different from that of His. All the cells of the epithelial anlage at first assume a lymphoid character. Later, some of these cells reassume their epithelial nature and then form the corpuscles. His conclusions for teleosts and amphibians are similar to the above results which he obtained from the lizard.

Ver Eecke (28), 99, for the frog, describes the leucocytes and connective tissue cells as invading the thymic anlage and separating the epithelial cells. The epithelial cells, separated by the mesenchymal elements, lie at first in groups or singly. They go through a cycle of two phases, a stage of growth, and a stage of involution. In the former stage, they increase to three or four' times their original size and their cytoplasm differentiates into circular layers like the coats of an onion. The majority are monocellular. Some cells grow together making a more complex multicellular type. There are some intermediate forms, cells with a dense dark protoplasmic body, indistinct striations, and a nucleus partly or completely hidden in a precocious degeneration. In the stage of involution, which sets in early, the.cytoplasm degenerates by the formation of vacuoles containing a hyaline liquid. The liquefaction may be in the form of a diffuse vacuolization, a large central vacuole, or a peripheral vacuole circular in section. The nucleus loses its affinity for stains, becomes deformed, breaks up, and finally disappears. The corpuscles are finally absorbed. They never contain erythrocytes. The cells do not degenerate to form a corpuscle. The liquefaction forms an internal secretion which is forced out by the muscle tissue in the reticulum.

Entirely different results on amphibians are reported by Nusbaum and Machowski (19), o2. These investigators revive the old idea of Afanassiew, accepting his results except that they think the adventitia as well as the endothelium of the blood-vessels takes part in the formation of the corpuscles. They find erythrocytes in the corpuscles. These erythrocytes either gradually shrivel and disappear, or they are absorbed by leucocytes or endothelial cells. The leucocytes after digesting the hæmoglobin of the erythrocytes become eosinophile cells which are numerous in the thymus. 
Wallisch $(30), 03$, measured the volume of the human thymus and of the corpuscles of Hassall at various stages. He finds that the total volume of the corpuscles of a 7-mo. embryo is $4.6 \mathrm{~mm} .{ }^{3}$ and of those of a 6 -mo. child, $174.6 \mathrm{~mm}$. The total volume of the thymus of a $78-\mathrm{mm}$. embryo, when it has already been partly transformed into adenoid tissue is only $6.8 \mathrm{~mm} .^{3}$ Since there is no evidence that the cells of the corpuscles multiply, he concludes that they cannot be regarded merely as remnants of the original epithelial anlage.

Disregarding the crude observations of the earliest investigators, there remain three distinct theories of the formation of the corpuscles of Hassall.

1. The epithelial anlage of the thymus is broken up by the invading mesenchymal elements. The separated masses of epithelial cells undergo further changes mainly of a degenerative nature to form the corpuscles. This was the belief of His and Kölliker. According to this interpretation, the corpuscles are to be regarded as remnants that have nothing further to do with the gland. Stieda, Maurer, and Ver Eecke held this view in a modified form. Stieda regarded the cells forming the corpuscles as epithelial remnants but admitted that they go through a stage in which, for a time, they lose their epithelial character. This is substantially the same as Maurer's view. He thinks that the cells of the epithelial anlage all become lymphoid, and that some of them afterwards reassume their epithelial nature and form the corpuscles. Ver Eecke regards the corpuscles as epithelial remnants but thinks that they are glandular in nature, not mere useless remains.

2. The corpuscles are formed from the proliferating walls of bloodvessels. This idea was suggested by Cornil and Ranvier and elaborated by Afanassiew. Nusbaum and Machowski accept Afanassiew's view except that they believe the adventitia of the blood-vessels as well as their endothelium takes part in the formation of a corpuscle. These investigators thought that the formation of the corpuscles is connected with the involution of the thymus.

3. The corpuscles are formed from reticulum cells of the medulla and grow by apposition of the surrounding cells. This view was advanced by Ammann. Ammann thought that the reticulum is of connective tissue origin. He also believed that leucocytes formed the central part at least of some corpuscles. Hermann and Tourneux accepted Ammann's results, except that they ascribed an epithelial origin to the reticulum. (I do not know whether they accepted the origin from leucocytes described by Ammann.) Ammann thought that the corpuscles formed because of a physiological decrease in the rate of growth in the medulla. 
My own observations on the development of the corpuscles of Hassall in pig embryos, will now be considered. The medulla, as previously described, begins to form from the epithelial syncytium usually near the center of the lobule. It is first recognized by its more marked reaction with cytoplasmic stains such as Congo red. Shortly after the medulla begins to form, the earliest stages of the corpuscles may be observed. A few corpuscles have appeared at $9.5 \mathrm{~cm}$. I did not find them earlier. They are all formed from the epithelial syncytium of the medulla.

Before beginning this discussion I will explain the use of my terms. By a corpuscle of Hassall, I mean a modified area of the epithelial syncytium of the medulla, containing at some period of its development, one or more nuclei, and whose cytoplasm has been in part or entirely transformed into colloid. The term colloid is applied to various substances probably of widely different chemical nature, but is fairly adapted to our imperfect knowledge. I shall use the term here in the restricted sense employed by Ziegler,' i. e., hyaline substances of epithelial origin, that do not give the reactions of mucin.

Colloid in the corpuscles of Hassall does not usually appear as solid masses in its early formation, but as fibers, granules, or sheets which are separated by more or less cytoplasm that is not yet changed. This stage I have called, "colloid in formation" $(c f)$. It later assumes a more solid homogeneous appearance which I call solid colloid $(c s)$. Often the solid colloid stains intensely with cytoplasmic stains. 1 call this kind solid deeply-staining colloid $\left(\begin{array}{ccc}c & d\end{array}\right)$. In later stages, the colloid often loses its affinity for cytoplasmic stains, staining a very pale color or not staining at all. I call this variety old colloid $(o c)$.

According to their mode of development, the corpuscles of Hassall may be classified as follows:

A. Concentric Corpuscles.

a. Simple.

1. Ordinary type.

2. Fpithelioid type.

3. Cystic type.

b. Compound.

B. Irregular Corpuscles.

a. Compact type.

b. Reticular type.

-Gen. Pathology, 10th ed., Warthin's translation, p. 205. 
A. The concentric corpuscles include those that from their earliest appearance are concentric in structure. Adopting Ecker's classification, I distinguish simple concentric corpuscles and compound concentric corpuscles.

(a) Three types of simple concentric corpuscles are to be considered. (1) The ordinary type is far more numerous than any other. The earliest recognizable stage is shown in Plate II, Fig. 11. A nucleus $(n)$ of the syncytium of the medulla has enlarged to perhaps twice its ordinary volume and has lost the ability to stain in the characteristic way with hæmatoxylin. Its sap is clear and a few reddish stained granules represent its chromatin. Around it in the cytoplasm is an indistinct uneven layer of colloid $(c f)$. The colloid is not yet solid and is being formed in concentric fibers or sheets. A slightly later stage is shown in Plate II, Fig. 14 and Fig. 15 (left side of figure). Some of the colloid (c s) next to the nucleus is now solid. The next stage is shown in Plate II, Fig. 15 (right side of figure). These corpuscles show a thick layer of colloid $(c s d)$ that stains intensely with Congo red. Just outside the deeply staining colloid, colloid in formation may be seen. The nuclei are clear, and have become smaller and irregular in outline. The colloid seems to be pressing upon them and obliterating them. The colloid transformation gradually involves the adjacent cytoplasm of the syncytium until other nuclei are involved. The corpuscle has now reached the condition shown in Plate II, Fig. 12. The central area $(o c)$ is solid, the nucleus having disappeared entirely. Another $\left(n^{\prime}\right)$ is nearly obliterated by the colloid. Part of the central area $(o c)$ no longer stains intensely, and it is breaking loose by the formation of a concentric space. Several nuclei are surrounded by colloid in formation. Their long axes are nearly in a tangential direction. These nuclei are clear but only moderately swollen.

In the further development of the corpuscle (Plate III, Fig. 17 and Plate II, Fig. 7$)$, the central area $(c s d)$ increases in size. The nuclei involved in this area become obliterated probably by the pressure of the colloid and are no longer distinguishable. This central area usually splits off and may break up into many smaller masses. The peripheral part of the corpuscle increases by extension of the colloid formation into the adjacent part of the syncytium. This extension takes place in the early stages by direct progressive involvement of the immediately adjacent cytoplasm; in later stages (Fig. 7), by the formation of concentric lamellæ which cut off unchanged areas of cytoplasm. The lamellæ increase in size and number, the cytoplasm included between them is changed into colloid. They finally become closely packed, giving the characteristic and 

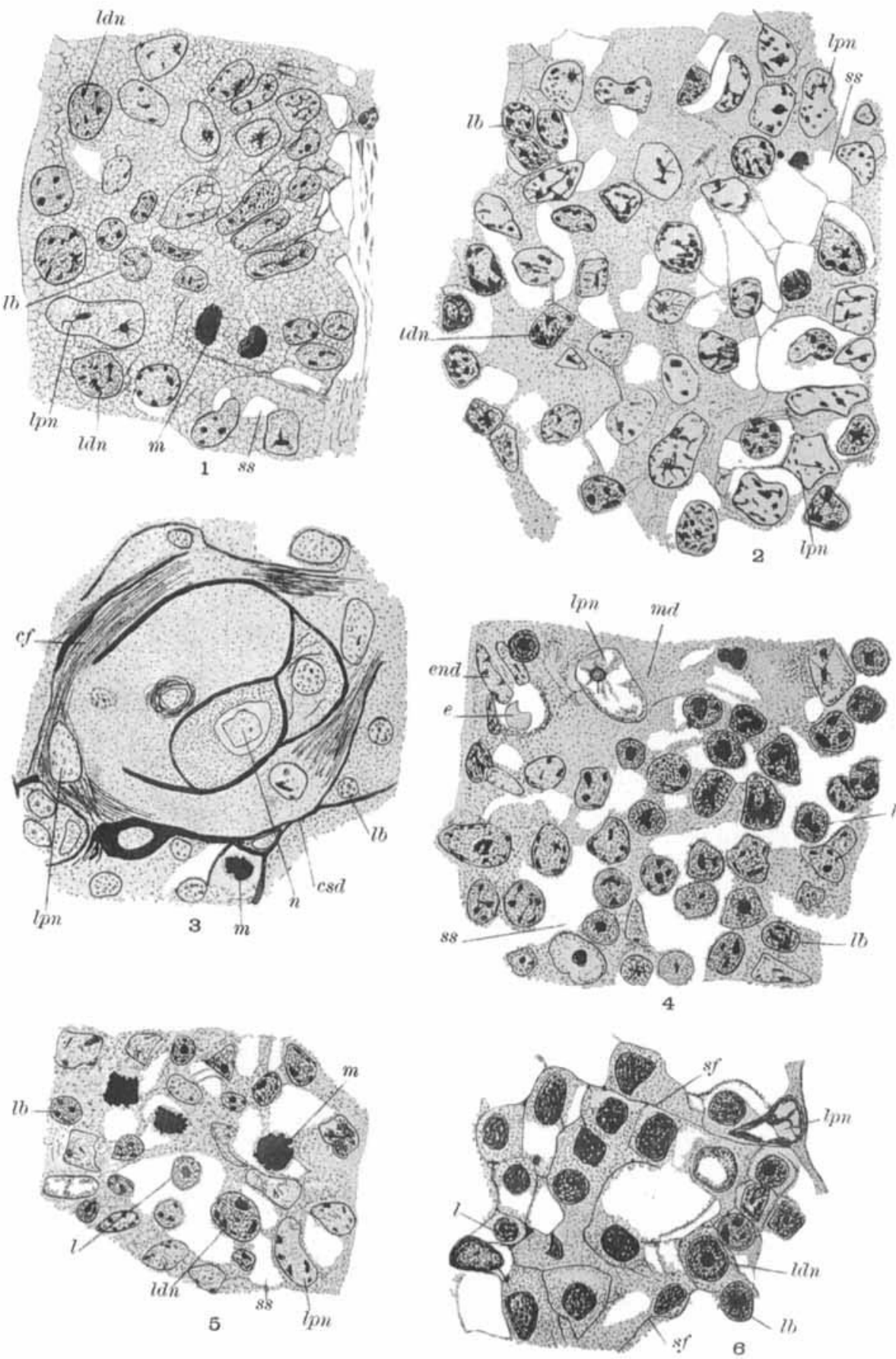


\section{E. T. BELL.}
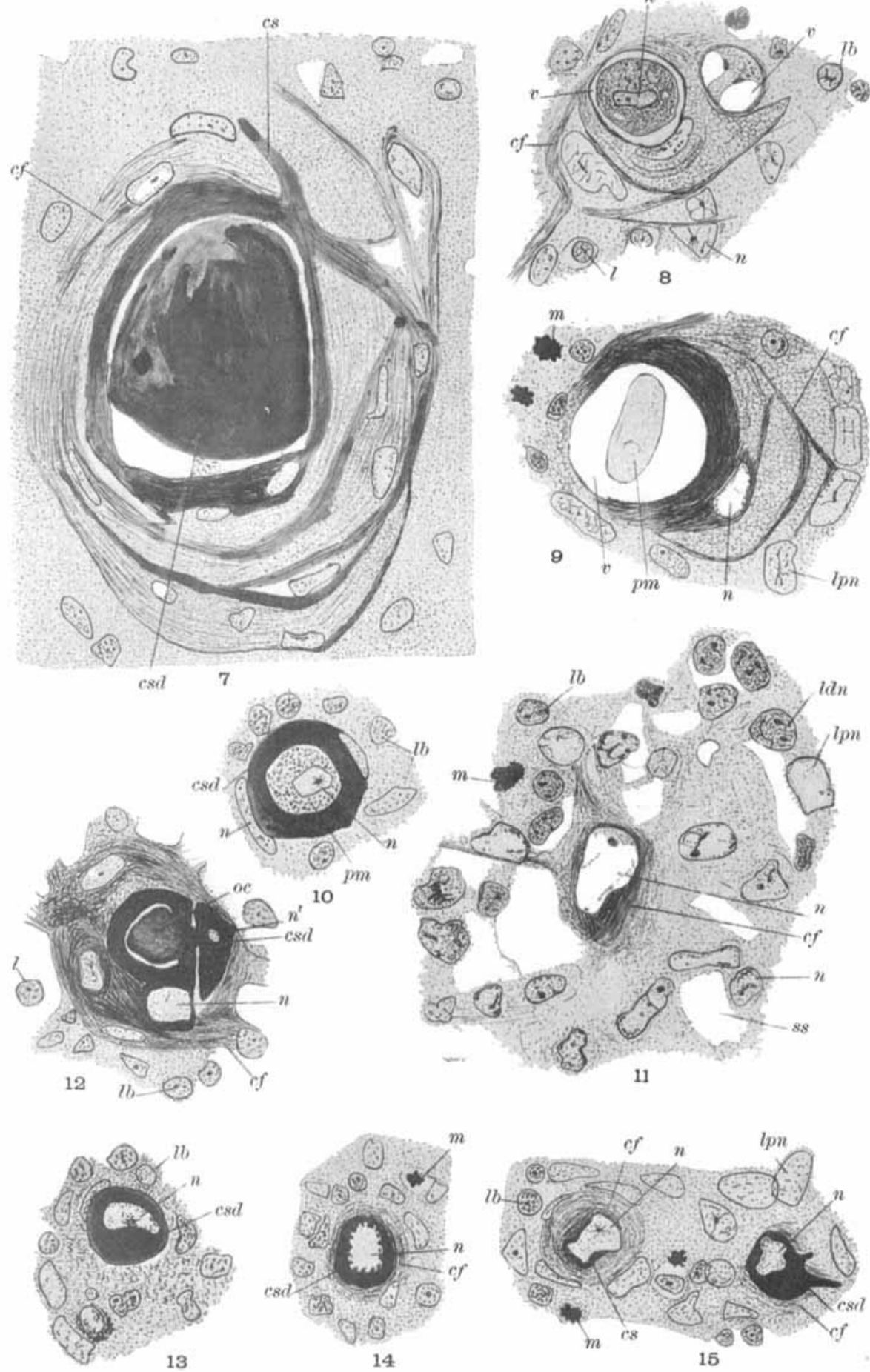

AMERIOAN JOURNAL OF ANATOMY--VOL $v$.

E. T. BELL, DEL. 
E. T. BELL.
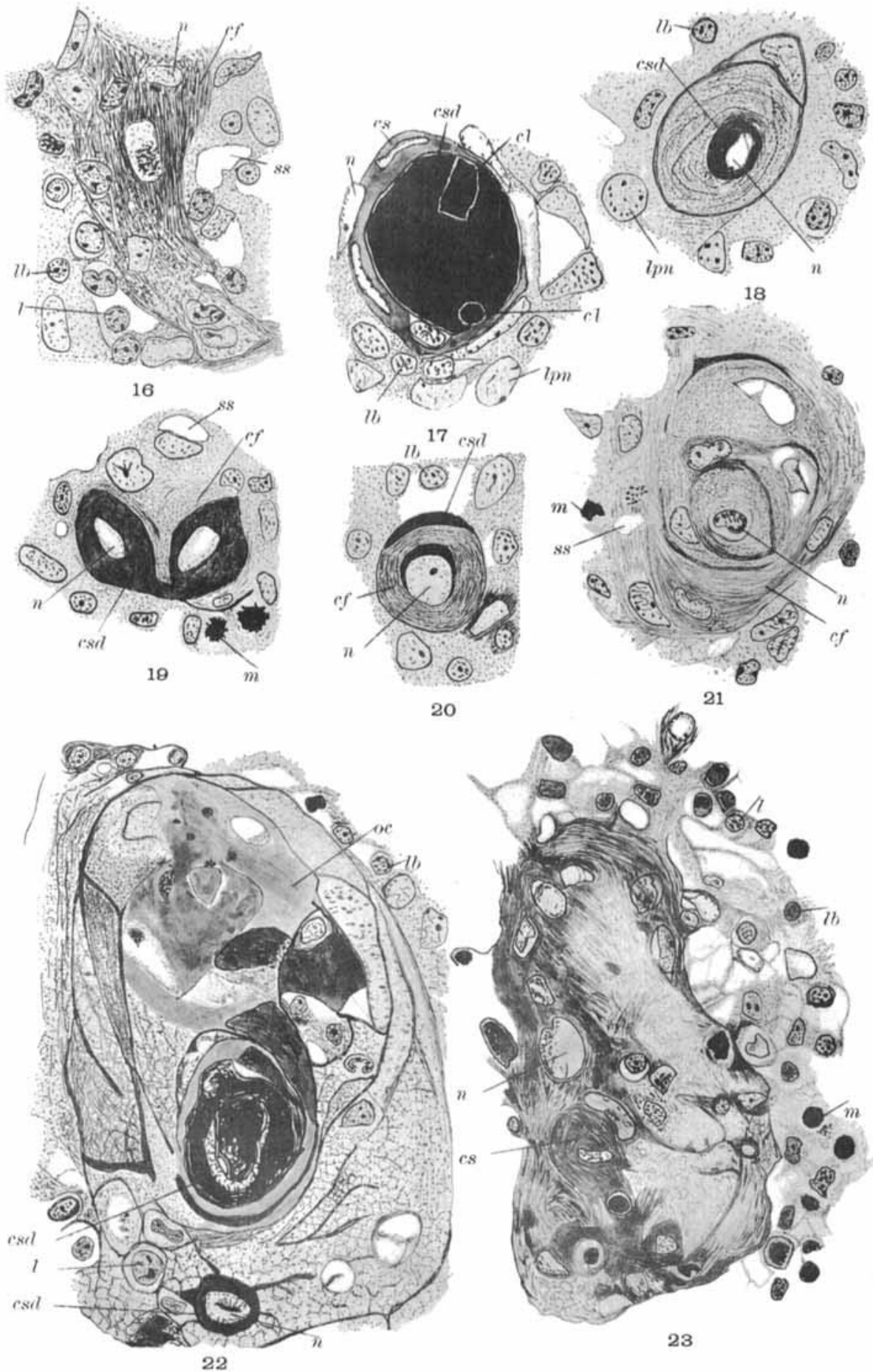

E. T. BELL, OEL. 
well-known onion-like structure found in the fully-formed corpuscle. The nuclei that are enclosed between the lamellæ gradually lose their chromatin and become flattened out. They do not swell and are not obliterated. It seems that swelling occurs only in nuclei that are surrounded by deeply staining colloid, and that this change is preparatory to their obliteration by or transformation into colloid. The amount of the corpuscle that breaks up to form the softer center is very variable. The size of the center usually seems to increase with the age of the corpuscle.

Plate III, Fig. 21, shows a variation from the ordinary concentric type. The central nucleus $(n)$ stains reddish but is not enlarged. Most of the other nuclei are unchanged. All the colloid $(c f)$ is in the early fibrous and granular stage.

From $20 \mathrm{~cm}$. to full term many corpuscles show masses of calcareous material in or near the center. This material rarely appears in younger corpuscles (Plate III, Fig. 17, cl). It stains a violet blue with Delafield's hæmatoxylin.

The majority of the corpuscles of Hassall belong to the ordinary type of simple concentric corpuscles described above. It is very clear that they have nothing to do with blood-vessels. They never contain erythrocytes nor anything resembling them. Rarely a lymphoblast or leucocyte is found inside the corpuscle. These seem to be usually involved in the corpuscle like ordinary stroma nuclei during the formation of the lamellæ. (Their occurrence in other types will be discussed later.) It is also clear that these corpuscles arise from the syncytium of the medulla. They are epithelial in origin, since the entire stroma of the gland is derived from epithelium, but they are certainly not remnants of the original epithelial anlage. Neither are they formed from lymphoidlike elements that reassume their epithelial nature as Maurer described for the lizard.

Some of Ammann's observations are in accord with my results. The swelling of the nucleus was noted by Ammann as the first step toward the formation of the corpuscle. It should be noted, however, that rarely a corpuscle begins to form as a mass of colloid out in the cytoplasm and involves nuclei secondarily. I cannot distinguish his "Stadium der Transparenz" for I cannot be sure that a corpuscle is beginning to form until some colloid is present. The formation of the colloid is associated with the swelling of the nucleus. His other three stages, "Stadium der colloiden Entartung," "Stadium der Verkalkung," and "Stadium des Zerfalls" are easily seen. T have never seen corpuscles begin in leucocytes as Ammann described. His statement that the corpuscle grows by apposition of reticulum cells is true in a modified sense. He thought that 
the outer part of a corpuscle is formed of reticulum cells that have moved up and flattened themselves out around it. The description just given shows that the corpuscles are never composed of distinct cells, and that the increase in size is due to an extension outward of the colloid formation and not to a moving in of the adjacent tissue.

The concentric form of this type of corpuscle is due at first to its being formed around a spherical or ellipsoidal nucleus. The swelling of this nucleus creates a centrifugal pressure in the adjacent cytoplasm. Before or during its transformation into colloid, the cytoplasm also increases in quantity. That the cytoplasm increases in quantity is shown by the fact that the nuclei are fewer in the corpuscle than in any adjacent area of the syncytium of equal size. This centrifugal pressure presses the newly formed colloid into concentric lamellæ. It at first turns the long axes of the nuclei tangentially, and later flattens them and makes them concave toward the center.

2. The epithelioid type of corpuscle is characterized by large areas of cytoplasm so marked off by colloid lamella as to give the appearance of a mass of large epithelial cells. They may contain only one nucleus embedded in a well-defined area of cytoplasm (Plate III, Figs. 18 and 20). These correspond to the monocellular corpuscles that have been described for lizards and amphibians. They are rare in the pig. I have not been able to trace these very far, as they soon become indistinguishable from other forms. The only difference I have noted is that the outer colloid lamellæ begin to form early, causing the peculiar appearance of a large epithelial cell. Again the epithelioid type may present an appearance such as shown in Plate I, Fig. 3. These do not seem to be formed around any special nucleus. The outer colloid lamellæ form before any center has been established, marking off large cytoplasmic areas that may look like large cells. The centrifugal pressure of expansion caused by the great increase of cytoplasm in this area determines the concentric form in these corpuscles. Pure epithelioid corpuscles are very rare, but epithelioid areas in other corpuscles are not uncommon. The occurrence of epithelioid areas in corpuscles of the ordinary type shows that it is due to variations in a fundamentally similar process.

3. In the cystic type of corpuscle, the central part, instead of becoming transformed into colloid, undergoes early liquefaction, forming vacuoles. The central nucleus does not increase in size as in the ordinary type, but shrivels up and disappears. The corpuscle begins by the formation of outer colloid lamellæ-the central mass is not changed into colloid. In Plate II, Fig. 10, the central area $(p m)$ is undergoing a diffuse liquefaction. The nucleus $(n)$ is colorless and shrunken. In Plate II. 
Fig. 8 (right side of figure), the central area has formed two large vacuoles $(v)$. On the left side of the same figure, a concentric vacuole $(v)$ has formed, separating off a central spherical nucleated mass of protoplasm. The nucleus of this mass of protoplasm is shrunken and the cytoplasm shows many small vacuoles. The corpuscle shown in Plate II, Fig. 9, is probably a later stage of the form just described. The central protoplasmic mass has become converted into an ellipsoidal pale body $(p m)$. The small circular body in this shriveled mass is probably the nucleus. Some corpuscles like the one shown in Fig. 9 are found in which the central mass has entirely disappeared. The further growth of corpuscles of this type seems to be by formation of colloid lamellæ as in the ordinary type. They soon become indistinguishable from other forms.

The cystic type of corpuscle is rare in the pig. This evidently corresponds to the form in amphibia that misled Nusbaum and Machowski into reviving Afanassiew's theory. The central masses, in Figs. 8 and 9, might readily be mistaken for red corpuscles in animals in which these cells are nucleated. But the red cells of the blood of the pig are not nucleated at this stage. I have traced a number of these corpuscles (as well as those of other types) in serial sections and have never seen any indications of a connection to blood-vessels. Nusbaum and Machowski (19), (Fig. 1, c, S. 116) show a corpuscle which is similar to my Fig. 9. It will be noted that the central space in neither of these figures is lined by endothelium. The early form of corpuscle shown by Nusbaum and Machowski (Fig. 1, d, S. 116) is very probably a normal bloodvessel with cubical endothelium. I have often found such vessels with cubical endothelium in the interlobular tissue of the pig's thymus at 10 $\mathrm{cm}$. to $12 \mathrm{~cm}$. They probably may be found at other stages also. In the thymus of a kitten, injected by the intra-vitam Prussian blue method previously described, the majority of the corpuscles were found to be in early stages. The injection did not penetrate any corpuscle. I had a somewhat better opportunity to study the relations of the corpuscles to the blood-vessels in a $14 \mathrm{~cm}$. human embryo. Here the vessels of the thymus were all very much distended with blood and the corpuscles were in early stages. No blood cells were found in the corpuscles.

(b) Compound concentric corpuscles are formed whenever two or more simple concentric corpuscles begin to form so close together that they come in contact during their later growth. An early stage of such a corpuscle is shown in Plate II, Fig. 15. The colloid lamellæ are formed around each center until they come in contact; they are then formed around both centers. In Plate III, Fig. 22, a compound concentric cor- 
puscle is shown. There are three simple concentric corpuscles in itone of them (the lowest in the figure) in a very early stage. Several lamellæ are common to the older corpuscles, and one is common to all three. This arrangement of the lamellæ is a mechanical effect of the tension in the cytoplasm, due to the centrifugal pressure from the two centers. The size of the separate centers in a compound corpuscle depends upon the stage they have reached when they come in contact. If a compound corpuscle be formed by the union of two simple corpuscles in an early stage, as in Plate III, Fig. 19, all indications of its compound nature are soon lost. A corpuscle originally compound may, then, in later stages, become indistinguishable from simple corpuscles. The simple corpuscles uniting to form a compound concentric corpuscle may be of any of the types previously described.

\section{B. Irregular Corpuscles.}

This group includes those corpuscles which are not at first concentric. Concentric areas may appear later. According to the classification previously given, I distinguish a compact type and a reticular type.

(a) The compact type (Plate III, Fig. 16) first appears as a compact area of syncytium of irregular shape. It is recognizable by the colloid it contains. The nuclei are not noticeably increased in size and have no regular arrangement. Their chromatin still stains dark with nuclear stains. The colloid $(c f)$ is not yet solid. The corpuscle has no distinct center. These corpuscles grow by direct colloid transformation of the adjacent syncytium. No distinct lamellæ are formed. The colloid may remain in the fibrous condition shown in the figure $(c f)$ or it may become solid, but it never reaches the deeply staining condition unless a concentric area be established.

A later stage of this type is shown in Plate III, Fig. 23. The corpuscle is sharply marked off from the syncytium. Some of its colloid is solid. A concentric area $(c s)$ is beginning to form. The nuclei are not markedly different from those of the adjacent syncytium. These corpuscles may become large and branched. Often one or more concentric areas are developed after the corpuscle has attained considerable size. By the growth of these concentric areas, irregular corpuscles may become converted into concentric corpuseles.

(b) The reticular type is produced by colloid formation in the ordinary reticulum of the medulla. In the types previously described, the spaces of the reticulum are usually obliterated as the colloid formation advances; but in this form the spaces persist as a part of the corpuscle. Pure reticular corpuscles vary greatly in size, sometimes involving only 
one node of the syncytium. They are never concentric, and never form lamellæ. Reticular areas often occur in other forms of corpuscles. In this way leucocytes are often involved in the corpuscle, since they lie in the spaces of the reticulum. Lymphocytes often get into a corpuscle in the lymphoblast condition, being cut off by the formation of lamellæ outside thein (Plate III, Fig. 22). The leucocytes shut in the corpuscle in this way during development may not degenerate. They probably persist and help to remove the corpuscle in its final stages of degeneration.

The amount of expansion of the cytoplasm before or during the colloid transformation is probably small in the irregular reticular corpuscles, since it does not obliterate the spaces of the syncytium. In the compact type, the spaces of the syncytiurn are obliterated and there is evidence of some expansive force (note the arrangement of the nuclei in the upper part of Fig. 23, Plate III). In the figure referred to, the number of nuclei in any part of the corpuscle is less than in an equal area of the adjacent reticulum. These facts indicate that there is an expansion of the cytoplasm. That this expansive force does not produce a concentrie form is due primarily to the fact that there is no expansion of a nucleus and distinct center of formation as is present in concentric corpuscles of the ordinary type. The absence of the onion-like structure in irregular corpuscles is due to the fact that the colloid is not laid down in lamellas.

Significance of the corpuscles of Hassall. It has been shown in the preceding pages that the corpuscles of Hassall in the pig are not epithelial remnants, and also that they are not formed from blood-vessels. 'There is no evidence connecting their development with the involution of the thymus, for they begin to form before the lymphoid transformation is complete and are most numerous when the thymus is at the height of its development. I have not been able to see the decrease in the rate of growth of the medulla described by Ammann, and even if such dirl occur it is difficult to understand how it could cause the formation of a corpuscle.

The above theories are, therefore, inconsistent with the facts of development in the pig. It seems to me that the formation of a corpuscle is not to be regarded as a process of degeneration. 'The fact that the formation of colloid is an essential feature in the development of every corpuscle is a strong argument that it is a form of secretion such as occurs in its neighboring branchial derivative, the thyroid. The fact that the corpuscles differentiate in an apparently uniform syncytium is further evidence against a theory of degeneration. Since the lymphocyte-forming function of the thymus is probably secondary, it is not 
unreasonable to suppose that its primitive function was the formation of a colloid secretion such as occurs in the thyroid, and that the corpuscles are abortive expressions of this primitive function."

\section{Giant Cells.}

Polykaryocytes may often be seen in the medulla. These bodies develop from the syncytium of the medulla. They are first noticeable as groups of small spherical nuclei in a solid area of the syncytium. These nuclei stain with medium intensity and are all very similar in size and color. The area containing this group of nuclei becomes a well-defined node of the reticulum and persists as such. A polykaryocyte is, therefore, a large node of the reticulum containing a number of small nuclei very similar in appearance. These cells often occur in groups. They are entirely distinct from the corpuscles. They are evidently similar to the polykaryocytes found in bone marrow and other lymphoid tissues.

\section{Summary.}

The following is a resume of the development of the thymus in the pig:

The thymus of the pig is probably developed entirely from the endoderm of the third gill pouch.

By a gradual process of vacuolization and liquefaction of the cytoplasm, the epithelial syncytium of the thymic anlage is converted into a cellular reticulum.

From the first appearance of vacuolization, three types of nuclei are present: large pale nuclei; small dark nuclei (lymphoblasts), and large dark intermediate forms.

The lymphoblasts gradually break loose from the cellular reticulum, moving into its spaces and forming lymphocytes. Mitoses are most numerous at the period of the most rapid formation of lymphocytes. The medulla continues to form lymphocytes at least as late as birth.

Lymphocytes appear in the connective tissue around the thymus shortly after they are formed; and lymphoblasts, which are distinguishable from lymphocytes only by being embedded in the syncytium, are present in the thymus a long period before lymphocytes are found anywhere in the neighborhood of the thymus.

The cellular reticulum of the earlier stages persists in a modified form as the reticulum of both cortex and medulla. It retains more cytoplasm

\footnotetext{
${ }^{7}$ Ver Eecke (28) believes that the corpuscles in amphibians are of a glandular nature.
} 
in the medulla. Practically all the reticulum of both cortex and medulla, as well as the lymphocytes, are, therefore, of epithelial origin.

The corpuscles of Hassall develop from the syncytium and are, therefore, epithelial in origin. They are, however, not to be considered as remnants of the original epithelial anlage.

In development various types of corpuscles are distinguished. The ordinary type of concentric corpuscles first appears as an enlarged clear nucleus around which colloid is being formed. Before or during the formation of colloid, the cytoplasm increases in quantity, filling the spaces of the reticulum and producing a centrifugal pressure which shapes the newly-formed colloid into concentric lamellæ and flattens the neighboring nuclei, making them concave toward the center. The central nuclei usually become obliterated.

The epithelioid type is distinguished by its resemblance to large epithelial cells, this appearance being due to the formation of colloid lamellæ around large areas of clear cytoplasm. The central part of the corpuscle usually remains unchanged until after some of the colloid lamellæ are formed.

The cystic type differs from the ordinary type only in that the central part undergoes vacuolization instead of colloid transformation. Those with concentric vacuoles may simulate blood-vessels containing nucleated red cells. Corpuscles never contain erythrocytes; neither can they be injected at any stage of development. Serial sections also show that there is no connection to blood-vessels at any stage.

Compound concentric corpuscles are formed by the union of two or more simple concentric corpuscles during development.

Irregular corpuscles are not concentric in arrangement, and are formed in the syncytium in an irregular manner. In the compact type of irregular corpuscles, concentric areas may form.

The formation of colloid is an essential feature in the development of every corpuscle, and is not to be considered as a process of degeneration.

Since the conchusion of my work and after my manuscript was given to the publishers, two articles dealing with the thymus have appeared.

$\mathrm{Ph}$. Stöhr (Ueber die Thymus, Sitzungsberichte der phys.-med. Gesellschaft zu Würzburg, June 8,1905 ) believes that the thymus first epithelial in nature becomes converted entirely into small cells of lymphoid appearance. Later the large reticulum cells are formed from these by enlargement. The corpuscles of Hassall are formed by the massing together and enlargement of these lymphoid-like cells. The small round cells of the gland are epithelial in origin but are to be regarded not as lymphocytes but as epithelial cells. The thymus is not a source of lymphocytes. 
The author apparently believes that none of the small round cells leave the gland though he admits that lymphocytes enter. But as mentioned above the zone of connective tissue immediately around the head at $7 \mathrm{~cm}$. may contain even more lymphocytes than are present inside the gland at that time If these are all entering the gland then it is probable that most of the small round cells are really lymphocytes. This conception then does not simplify the problem but is only a theoretical compromise between the two views as to the origin of the lymphocytes.

J. Aug. Hammar (Zur Histogenese und Involution der Thymusdrüse, Anat. Anz. Bd. XXVII, June 17, 1905) regards the reticulum as formed from the epithelial anlage but thinks the evidence at hand insufficient to decide the question as to the origin of the lymphocytes. He finds lymphocytes outside the thymus in many animals (man, cat, chick, frog) before any are present inside the gland. The corpuscles of Hassall develop from the epithelial reticulum and undergo hyaline (colloid?) degeneration.

My description of the formation of the corpuscles of Hassall differs essentially from Hammar's, in that I believe the formation of the corpuscle consists in the expansion of the cytoplasm of the syncytium and its conversion into colloid. Hammar did not recognize "colloid in formation," though he speaks of the coarse fibrillar structure of the protoplasm. He did not describe such corpuscles as are shown in Fig. 7, Plate II.

The considerations presented above in favor of the epithelial origin of the lymphocytes seem to me much stronger than those given by Hammar. His statements as to the presence of lymphocytes around the thymus before they are present inside are to be taken with some reservation inasmuch as he mentions small round cells separate from the syncytium earlier, but regards them as degenerating epithelial cells (S. 65). His figure from the human fœtus (Fig. 18, S. 66) does not seem to be strong support for his statement. Certainly many lymphocytes are present in the pig thymus when the reticulum is broken up as much as shown in the figure referred to. It is also to be borne in mind that the different parts of the thymus undergo the lymphoid transformation at different times and that a single section may therefore be misleading.

\section{LITERATURE.}

1a. Afanassiew, B.-Ueber die concentrischen Körper der Thymus. Archiv f. mikr. Anat., Bd. XIV, 1877.

1b. Weitere Untersuchungen über den Bau und die Entwickelung der Thymus und der Winterschlafdrüse der Säugethiere. Archiv f. mikr. Anat., Bd. XIV, 1877.

2. Aumanr, A.-Beiträge zur Anatomie der Thymusdrüse. Basel, 1882.

3a. BEARD.-The development and probable function of the thymus. Anat. Anz., Bd. IX, 1894.

$3 \mathrm{~b}$. - The true function of the thymus. Lancet, 1899.

4. Bons, G.-Ueber die Derivate der embryonalen Schlundbogen und Schlundspalten bei Säugethieren. Archiv f. mikr. Anat., Bd. XXIr, 1883.

5. Cornil et Ranvier.-Manuel d'histologie pathologique. Paris, 1869, p. 135 (cited from Ammann). 
6. Ecker.-Art. “ Blutgefässdrüsen,” Wagner's Handw. der Phys., III (cited from Ammann).

7. Friedleben, A.-Die Physiol. der Thymusdrüse. Frankfurt, 1858.

8. Gulland.-The Development of adenoid tissue with special reference to the tonsil and thymus. Laboratory Reports issued by the Royal College Phys., Edinburgh, Vol. III, 1891.

9. Günzburg.-Ueber die geschichteten Körper der Thymus. Zeitschr. f. klin. Med., Bd. VI, 1857, S. 456 (eited from Henle und Meissner. Bericht über die Fortschritte der Anat. u. Physiol.).

10. HASSALL.-The microscropical anatomy of the human body in health and disease. London, 1846 (cited from Ammann).

11. Hermann et Tourneux.-Article thymus, Dict. encycl. des Sciences Médicales. Troisième Série, 17, 1887.

12a. HIs, W.-Zeitschrift f. wiss. Zoologie, Bd. X, S. 348. Leipzig, 1860.

12b. - Anatomie menschlicher Embryonen. Leipzig, 1880, S. 56.

13. JACKson, C. M.-Zur Histologie und Histogenese des Knochenmarkes. Archiv f. Anat. und Physiol,, Anat. Abth., 1904.

14. Kastschenko.-Das Schicksal der embryonalen Schlundspalten bei Säugethieren. Archiv f. mikr. Anat., Bd. XXX, 1887.

15. KLein.--Neuere Arbeiten über die Glandula Thymus. Centralbl. f. allg. Pathol. u. pathol. Anat., 1898.

16. Langerhans und Savelifw.-Beiträge zur Physiologie der Brustdrüse. Virchow's Archiv, Bd. 134, 1893.

17a. Maurer.-Schilddrüse und Thymus der Teleostier. Morph. Jahrb., Bd. XI, 1886.

17b. - Schilddrüse, Thymus, und Kiemenreste bel Amphibien. Morph. Jahrb., Bd. XIII, 1888.

17c. - Schilddrüse, Thymus, und andere Schlundspaltenderivate bei der Eidechse. Morph. Jahrb., Bd. XXVII, 1899.

17d. - - In Hertwig's Handbuch der Entwickelungslehre der Wirbelthiere, Lief. 6-8, S. 131 ff., 1902 .

18. Monguid.-Sulla glandula timo. Parma, 1885 (cited from Prenant).

19. Nusbaum, J., und Machowski-Die Bildung der concentrischen Körperchen und die phagocytotischen Vorgänge bei der Involution der Amphibienthymus, etc. Anat. Anz., Bd. XXI, 1902.

20. Nusbaum, J., und Prymak, T.-Zur Entwickelungsgeschichte der lymphoiden Elemente der Thymus bei den Knochenfischen. Anat. Anz., Bd. XIX, 1901.

21. Paulitzky.-Disquis. de stratis giandulæ thymi corpusculis. Habilitationsschr., Halis, 1863 (cited from Henle und Meissner's Bericht über die Fortschritte der Anat. und Physiol.).

22. Prenant.-Développement organique et histologique du thymus, de la glande thyroide, et de la glande carotidienne. La Cellule, Tome $\mathrm{X}$, 1894.

23. Prymak, T.-Beiträge zur Kenntnis des feineren Baues und der Involution der Thymusdrüse bei den Teleostieren. Anat. Anz., Bd. XXI, 1902. 
separate large areas of clear cytoplasm, causing the appearance of large epithelial cells. Colloid is being formed between the lamellæ and around several nuclei.

Fig. 4. From a 8.5-cm. pig embryo. Stained with iron-hæmatoxylin (not decolorized). The medulla has appeared. Lymphocytes are present between the epithelial cords.

Fig. 5. From a 7-cm. pig embryo. Stained with iron-hæmatoxylin and Congo red. A few lymphocytes have been formed. In the cellular reticulum are large pale nuclei, lymphoblasts, and large dark intermediate nuclei. The nuclei in mitosis are very compact.

FIG. 6. From the medulla of a 24-cm. pig embryo. Stained with Jackson's modification of Mallory's method (ref. in text). Many fibrillæ are seen in the syncytium.

\section{Plate II.}

Fig. 7. Ordinary type of simple concentric corpuscle. From a 16.5-cm. pig embryo. Stained with hæmatoxylin and Congo red. The rorpuscle is well advanced in development. Concentric lamellæ of colloid have been formed. The cytoplasm between the lamellæ is in an early stage of colloid transformation. Colloid fibers cut transversely appear as dots. The nuclei are becoming flattened by the pressure of expansion. The central mass stains irregularly and all traces of the nuclei in that region are gone.

Fig. 8. Two cystic concentric corpuscles. From a 16-cm. pig embryo. Stained with iron-hæmatoxylin and Congo red. On the left, a nucleated mass of protoplasm has been separated off by the formation of a vacuole annular in section. This might be mistaken for a blood-vessel containing a nucleated red cell. In this central protoplasmic mass the nucleus is shrunken and the cytoplasm vacuolated. In the small corpuscle on the right, two large vacuoles have formed.

FIG. 9. Cystic concentric corpuscle. From a 14-cm. pig embryo. Stained with hæmatoxylin and Congo red. The central protoplasmic mass is pale and shrunken. The small circular body in it probably is the remains of the nucleus. Colloid lamellæ are forming. Colloid fibers cut transversely appear as dots.

Fig. 10. Cystic concentric corpuscle. From a 10.5-cm. pig embryo. Stained with hæmatoxylin and Congo red. The center contains no colloid and seems to be softening. The nucleus is shrunken.

Fig. 11. Ordinary concentric corpuscle in a very early stage. From a 10.5-cm. pig embryo. Stained with iron-hæmatoxylin and Congo red. The nucleus is enlarged and colloid is forming around it. A few colloid fibers may be seen in the cytoplasm for some distance from the central nucleus.

FIG. 12. Ordinary concentric corpuscle. Several nuclei are involved. From a 10.5-cm. pig embryo. Stained with hæmatoxylin and Congo red. The deeply-staining colloid has completely obliterated the central nucleus (in the region $o c$ ), and nearly obliterated another $\left(n^{\prime}\right)$. Some of the colloid now stains pale $(0 \mathrm{c})$.

FIG. 13. Ordinary concentric corpuscle. From a 10.5-cm. pig. Stained with hæmatoxylin and Congo red. The central nucleus is being obliterated 
by the deeply-staining colloid. The neighboring nuclei are beginning to show the effect of the centrifugal pressure.

Fig. 14. Ordinary concentric corpuscle in an early stage. From a 10.5-cm. pig. Stained with hæmatoxylin and Congo red. A band of deeply-staining colloid has been formed. Just outside this is colloid in formation.

FIG. 15. Two simple concentric corpuscles which would have formed a compound concentric corpuscle. From a $10.5-\mathrm{cm}$. pig. Stained with hæmatoxylin and Congo red. The left corpuscle is a little more advanced than Fig. 11. The right corpuscle shows a large area of deeply-staining colloid which has pressed the nucleus into a small irregular shape.

\section{Plate III.}

Fig. 16. Compact irregular corpuscle in an early stage. From a 14-cm. pig embryo. Stained with hæmatoxylin and Congo red. The colloid is not yet solid. The nuclei are not essentially different from those of the adjacent syncytium.

FIG. 17. Ordinary concentric corpuscle. From a 12-em. pig embryo. Stained with hæmatoxylin and Congo red. There is a large, central, deeplystaining colloid mass in which calcareous deposits $(\mathrm{cl})$ have been made. The neighboring nuclei show the effects of the centrifugal pressure.

FIG. 18. Epithelioid concentric corpuscle in an early stage. From a 10.5cm. pig embryo. Stained with hæmatoxylin and Congo red. The outer colloid lamella marks off a nucleated mass of cytoplasm resembling a large cell. The nucleus is undergoing the same changes as occur in the central nucleus of an ordinary concentric corpuscle.

Fig. 19. Compound concentric corpuscle. From a 10.5-cm. pig embryo. Stained with hæmatoxylin and Congo red. This would have soon lost all evidence of its compound nature.

FIG. 20. Epithelioid concentric corpuscle. From a 10.5-cm. pig embryo. Stained with hæmatoxylin and Congo red. Some colloid is forming outside the circular area. Solid deeply-staining colloid is forming.

Fig. 21. Ordinary concentric corpuscle, showing a variation from the usual type. From a $16.5-\mathrm{cm}$. pig embryo. Stained with iron-hæmatoxylin and Congo red. The central nucleus is reddish but not enlarged. No solid colloid has been formed.

Frg. 22. Compound concentric corpuscle. From a 16.5-cm. pig embryo. Three centers are present. The pale colloid in the upper part is probably older than the deeply-staining variety. In the lower part of the figure, a young corpuscle is shown.

Fig. 23. Compact irregular corpuscle. From a 16-cm. pig embryo. Stained with hæmatoxylin and Congo red. Some of the colloid is solid. No definite center is present but one is beginning to form $(c s)$. The nuclei are not markedly different from those of the adjacent syncytium. 